\begin{tabular}{c} 
Volume and Issues Obtainable at Center for Sustainability Research and Consultancy \\
Review of Politics and Public Policy in Emerging Economies \\
ISSN: $2708-3829$ \& (E): $2708-356 X$ \\
Volume 2: No. 2, December 2020 \\
CSRC \\
Journal homepage: $\underline{\text { www.publishing.globalcsrc.org/rope }}$ \\
\hline
\end{tabular}

\title{
Informal Economy Enabling Tax Evasion and Money Laundering in Pakistan: An Analytical Study
}

\author{
Aamir Khan, Advocate at High Court Bahawalpur, Pakistan \\ *Naureen Akhtar, University Gillani Law College, Bahuddin Zakariya University, Multan, \\ Pakistan \\ Muhammad Danyal Khan, University Gillani Law College, Bahuddin Zakariya University, \\ Multan, Pakistan
}

Rao Imran Habib, University Gillani Law College, Bahuddin Zakariya University, Multan,

Pakistan

*Corresponding author's email: naureen.akhtar@bzu.edu.pk

\begin{tabular}{l}
\hline ARTICLE DETAILS \\
\hline History \\
Revised format: Nov 2020 \\
Available Online: Dec 2020 \\
\hline
\end{tabular}

Keywords

Informal Economy; Tax

Evasion and Money

Laundering, Pakistan

JEL Classification

H2O, $H 26$

\section{ABSTRACT}

Purpose: The primary objective of this article is to conduct an indepth analysis of the informal economy in Pakistan enabling money laundering and tax evasion in Pakistan. Furthermore, it also looks into the informal economy's implications for the economic growth of Pakistan. Finally, this article recommends potential reforms for formalization of economy of Pakistan for prevention of such crimes.

Methodology: A review regarding informal economy in Pakistan enabling money laundering and tax evasion with the help of prior studies has been conducted.

Findings: The formalization of the informal sector, according to this article, is important not only for raising tax revenues, but also for digital, skilled-based improvement of business activities, ramping up the operations and maintenance size of small businesses, increasing and diversifying production, and enhancing the lot of low-wage earners.

Implications: Lawmakers should focus on the implications of informal financial channels like hawala and hundi, which continue to operate beneath the radar of the informal sector. In order to identify money laundering, the Pakistani government must focus on strengthening and encouraging the digitization of the economy. The digitization of the economy is critical to the formalization of Pakistan's economy.

(C) 2020 The authors, under a Creative Commons AttributionNonCommercial 4.0

Recommended citation: Khan, A., Akhtar, N., Khan, M. D. and Habib, R. I. (2020). Informal Economy Enabling Tax Evasion and Money Laundering in Pakistan: An Analytical Study. Review of Politics and Public Policy in Emerging Economies, 2 (2), 131-138. 


\section{Introduction}

Pakistan's economy has been gradually growing for the past two decades. Due to discrepancies in macroeconomic policy and a reliance on foreign investment capital and the export industry to support economic growth, average yearly growth has been just $2 \%$ in recent years, less than $1 / 2$ that of Asia. (Bank, 2021). Pakistan now has a mixed economy, with state-owned businesses accounting for a major share of the gross domestic product, following various economic restructuring initiatives. Throughout its history, the nation has tried a number of business models. Pakistan's economic sector was mostly built on private industry at initially, but important sectors such as financial services, production, and transport were taken under national custody in the early 1970s (Burki, 2021).

Pakistan is dealing with a massive problem of informal economy, in addition to other economic issues. Alternative phrases for "informal economy" include "black economy," "shadow economy," and "underground economy." However, a precise definition of the phrase "informal economy" is difficult to come across. Commercial activity that takse place outside of the regular labor market are referred to as the informal economy. The official and irregular labor markets are usually described as "legal" and "unlawful," "market" and "non-market," "paid" and "unpaid". The informal economy is sometimes known as the "hidden" or "criminal" economy (Hub, 2021).

Long shifts, low wages and poor working conditions, poor job protection, and high employee turnover are all challenges that the informal economy produces, but it also presents a tax evasion problem when informal economy attempt to conceal money from tax regulators. Many businesses do not function solely in the formal or informal sectors. Those accused of having a lower level of tax morality are more concerned about corruption in the public sector, high tax rates, useless formalities, distributive inequality, and also what they perceive the government' unfairness. According to several international academics and local corporate executives, tax evasion is mostly caused by Pakistan's complex tax structure, which is compounded by a few other aspects. It has a plethora of taxes and tax collection organizations, some of which perform redundant responsibilities, and a lower-than-average tax take (Bokhari, 2020).

Similarly, Informal economy also enables money laundering. It occurs more frequently in countries where the risk of money laundering is minimal. Money laundering is prevalent in informal economy where there are no laundering restrictions, no system for storing bank or customer details, and financial secrecy is rigorously enforced. Cash outflows and inflows is simple for launderers in the informal economy. The informal economy exacerbates the current and fiscal deficits, as well as inflation, high interest rates, and unemployment. These instability in money demand produced by black money will inevitably have a negative impact on monetary and fiscal policy (Scanner, 2021).

The primary objective of this article is to conduct an in-depth analysis of the informal economy in Pakistan enabling money laundering and tax evasion in Pakistan. Furthermore, it also looks into the informal economy's implications for the economic growth of Pakistan. Finally, this article recommends potential reforms for formalization of economy of Pakistan for prevention of such crimes.

\section{Understanding the Concept of Informal Economy}

"Sir William Arthur Lewis" created the term "informal sector" ("1915-1991"). He was an economist from Saint Lucia who was awarded the "Nobel Memorial Prize in Economics" in 1979. He was talking to work that occurred outside of the official economy or the current industrial sector. "Economic Development with Unlimited Supplies of Labor," Lewis' greatest significant development economics paper, was released in 1954. (Manchester School). He 
developed the double sector model, sometimes known as the "Lewis model," in this paper. Lewis created a broad view of the development phase by combining a study of developed nations' collective history with the basic principles of mainstream economists. A "capitalist" sector grows by absorbing labor from a non-capitalist backward "subsistence" section, according to his thesis. So that companies do not increase profitability and employees might be compensated beyond their marginal revenue product, the sustenance industry is controlled by informal systems and cultural norms (Ranis, 2021).

Several academic researchers and institutions have elaborated on the idea of the informal economy. According to the International Monetary Fund, the informal economy is a worldwide phenomenon that consists of activities with market value that would contribute to tax income and gross domestic product if they were documented. On the one hand, people and businesses may opt to stay outside of the formal sector in order to avoid paying taxes and social contributions, as well as complying with norms and compliance issues. This is related to the widely held but incorrect belief that informality is mostly generated by businesses and people "cheating" to avoid taxation. Individuals, on the other hand, may rely on informal operations as a safety net because they lack the knowledge and skills required for formal work or because they are too impoverished to use public or financial institutions (Fund, 2020).

The informal sector, sometimes referred to as the "shadow market," "black economy," "shadow economy," or "gray economy," is a part of a country 's economy that is not recognized as a genuine revenue source. According to the World Bank, informal employment depletes countries' potential tax revenue and hinders regulatory oversight. People who work in the informal economy don't have to declare their earnings and don't have to pay taxes on them. Illicit actions included by this term include drug trafficking, money laundering, and human trafficking. Cleaning car windshields at traffic lights or working on building sites, for instance, are both legal employments. There is no employment security, no worker protection, and no state pensions in the informal sector. This group also includes those who intentionally do not report their earnings in order to avoid paying income tax. (News, 2021).

Furthermore, during the course of the Financial Action Task Force's twenty-five-year history, the list of predicate offenses for the Recommendations has developed and increased. The difficulty posed by this combination of circumstances is to apply processes and procedures established for the regulatory structures of a formal economy (which is typically the dominant economic order seen in industrialized countries) to an informal sector. The disparity between an anti-money laundering (AML) administration's framework and its actual execution outside of the underdeveloped country's economic constrained formal financial sector affects the administration's efficacy in combating money laundering. Shadow economies and irregular banking transactions originate and function outside of the reach of anti-money laundering procedures by definition (Vlcek, 2018).

\section{Informal Economy and Implications for Economic Growth of Pakistan}

The informal economy has a number of important repercussions for Pakistan's economic progress. The rise of the informal economy complicates policymakers' ability to design economic policies, particularly fiscal and monetary policies. Taxes are one of a government's primary sources of revenue. The informal sector, on the other hand, promotes a culture of tax evasion. Kemal (2007) assessed Pakistan's informal sector and determined that informal economy and tax evasion rose from the 1980s to the 1999s, then slowed until 2003. Tax evasion, on the other hand, is between 5. and 6.6 percent every year, with informal economy reaching 54.7 percent in 2005 . He goes on to argue that the tax system should be clear and easy to comprehend since loopholes in a complicated tax system entice individuals to avoid paying taxes that they would otherwise have to pay. 
There is a prevalent belief that the informal economy has poor efficiency and hence leads to low country growth. This article points out that informal sector is a cost to the government, particularly in terms of revenue generation in the near term as a result, it restricts regular economic growth by inflating the price of becoming formal that is taxpayers must cover the cost of tax evaders.

The informal economy's expansion has a substantial influence on institutionalization and governance. Numerous studies show that institutions have an impact on the growth of the informal sector. There is a negative correlation between the performance of organizations and the informal sector. The informal sector and corruption have a positive association, whereas the informal sector and the rule of law have a negative relationship. Fiscal policy, on the other side, has a significant influence on the growth of the informal economy. Sectors and tax burden proxies are moving in the same way. States with lower tax rates and fewer tax regulations are more likely to have a small informal economy (Qamar et al., 2021).

In Pakistan, the informal economy has an influence on the rights of the unregistered labor force, particularly women. According to estimates, in Pakistan, "20 million" "home-based employees" are part of informal economy in Pakistan, 12 million are women out of 20 million. In Pakistan, "home-based" employees, are not protected or regulated under any law. "ILO Convention C177 The Home Work Convention", 1996 has yet to be ratified. According to the "Pakistan Labour Force Survey", the country has 4.9 million home-based employees (working at "their own house" and "family or friend's dwelling"). According to a "UN Women" report from 2016, homebased employees contributed over Rs. 400 billion to the economy through their salaries, with women accounting for 65 percent of the total. In 2013-14, this sum was roughly equal to 3.8 percent of total GDP (Khan, 2017).

The informal economy, according to this article, is a diverse range of business activities, companies, employment, and employees that are not governed or regulated by the law. The term was first used to describe self-employment in tiny, unregistered businesses. It has been broadened to cover paid work in non-protected positions.

\section{Informal Economy enabling Tax Evasion in Pakistan}

The strongest indicator of a country's economic success is its capacity to generate income. Pakistan is a haven for shady lawmakers and dishonest merchants who make clandestine contributions, evade taxes, and loot the government treasury, leaving honest taxpayers and the government's main support base to face the consequences. The current national motto of Pakistan is "drawing the black economy (informal) into the tax net," which has become the rallying cry of the present government. Pakistan is dealing with a corporate tax evasion problem, with many unregistered firms attempting to avoid paying taxes. The issue may be more complicated for wealthier informal sector businesses. They are driven by labor law avoidance, a complex and rigid tax system, and lenient tax authorities who are more than happy to 'settle' through informal payments rather than legal taxes. As a result, most entrepreneurs find the idea that they are exempt from taxation absurd, even though it is challenging for both of them and state authorities to acknowledge the nature of these "taxes" (Ali, 2019).

Many academic scholars believe that one of the primary causes of the growth of the informal economy is the increase in income tax and economic security payment obligations. Taxes influence worker leisurely choices and boost labour market in the informal sector, or the untaxed part of the economy; economists are concerned about the distortions of this decision. The bigger the disparity between the total cost of labor in the formal sector and after-tax earnings, the larger the motivation to labour in the informal sector to cover the gap. This disparity is mostly 
determined by the social safety system and the total tax burden, both of which are important factors in the presence and growth of the informal economy. Even massive tax reforms with large tax rate deductions, however, will not result in a significant reduction in the informal economy (Fogel \& Agbi, 2021).

While tax evasion occurs even in countries with strong tax awareness and collection capabilities, Pakistan's incidence of over 50\% tax evasion is frightening and unacceptable. In Pakistan, there are three main causes for the high level of evasion. It is important to have a fair tax system. Salaried individuals are regarded to be easy prey for collecting taxes, and as a result, the state has struggled to broaden the revenue base. Due to their political clout, certain types of corporations get away with not paying their fair share of taxes, while ordinary individuals earning a monthly wage are overburdened. The informal economy's labor force does not pay taxes, making them a burden on the genuine and honest tax payer (Mehboob, 2019).

As a result, a growth in the informal economy leads to lower state revenues owing to tax evasion, which reduces the amount and quality of publicly funded goods and services, according to this article. In the end, this might lead to higher tax rates for individuals and businesses in the public sector, which is frequently accompanied with a reduction in quality of essential services.

\section{Informal Economy Enabling Money Laundering in Pakistan}

For most of us, the term "informal economy" will have distinct connotations. It may bring to mind thoughts of seasonal agricultural labourers in the fields for some. Housework, market stalls, laundering unlawful proceeds of crime, or drug trafficking outside the railway station are all options for others. The informal sector is the polar opposite of the formal economy, which is separated by laws and policy. As governments restrict or ban certain activities, it is possible that they will be pulled out of the formal sector and into the informal sector. If governments choose to delegate or regulate industry, which hasn't happened much in past few decades, it might become lawful, taxable, and integrated into the official economy once more. In addition, the informal sector's expansion is intimately tied to governmental social and economic policies.

According to Ponsaers (2008), the formally and informal sectors are not only interconnected, but they could also blend into one another in respect of their frameworks, methods of functioning, and operations in specific conditions. Because cartels have the greatest ability to enter the official sector where actions get complicated, especially where all of these conditions occur is likely one of the most beneficial crime-reduction initiatives that governments and international bodies might do. These activities may be an integral component of the informal economy, such as money laundering, selling narcotics, selling counterfeit products, owning a brothel, or bribing officials or they may be supplementary services, such as providing cabs for prostitutes.

Similarly, the legal concept of "hawala banking/hundi" ("informal plans to transfer money between different parts of the world") has ignited skepticism that it could be used for illicit practices and money laundering because it continues to operate outside of national and international regulatory structures designed to detect money laundering. "Hawala banking" may be used to facilitate illegal transition (the transfer of criminal proceeds), however it is highly reliant on trust, much like conventional banking. Strong social or ethnic ties may aid in the development of trust, but when hawala banking is used for illicit purposes, reputation and results, as well as the ability to remain anonymous, may be more important (Kagan, 2021).

"Hawala/Hundi", the informal transfers are used for either "money laundering" and terrorism financing, according to the "State Bank of Pakistan" ("SBP"). Unfortunately, Islamic insurgent group, armed resistance from neighboring countries, jihadist wings of political parties, Afghan drug smugglers, non-state actors, and local criminal gangs are proving to be factors of 
destabilization and bloodshed in Pakistan, with "Hawala/alternative remittance systems" being deemed the utmost bloodline of financial support for belligerent irrationality (Raza, 2017).

"Hawala and Hundi" are two of the most well-known words in Pakistan's economic environment, according to this article. Simply put, they are informal ways via which money is moved in and out of the nation. Hawala is a system made up of lending institutions and businesses from all over the world. It differs from formal trade channels (such as banks) in that it is based mostly on reputation and trust rather than written agreements. Anonymity, on the other hand, comes at a high cost for nations like Pakistan, since traffickers, drug dealers, and terrorist funders have brutally exploited this feature. It's no surprise that Pakistan is on the FATF's grey list.

\section{Informal Economy needs to be formalized for Prevention of Tax Evasion and Money Laundering}

The informal sector can be formalized in a variety of ways. Licensing, registration, organization and representation, legal structures, social welfare mechanisms, and commercial incentives/support are only a few of the topics covered. And different groups of the informal labor have varied definitions of formalization (WIEGO, 2021). The tax-to-GDP ratio in Pakistan is around $12 \%$. OECD countries, on the other hand, increase taxes equivalent to approximately $34 \%$ of their GDP. Pakistan's ability to support public investment is hampered as a result of this. When it does collect taxes, it mostly does so through regressive taxes on goods and services, that make about 6.3 percent of GDP. Direct taxes, which account for the remaining 4.2 percent of GDP, are mostly collected by firms withholding a proportion of monetary activities for the government (Raza, 2017).

The majority of developing nations' economies are built on informal, cash-based operations, which implies they are not covered by the tax revenue. As a result, they do not rely on people' voluntary tax compliance, which remains exceedingly low. The formalization of the taxing procedure is urgently required. The streamlining of registration processes and progressive registration costs for new tax payers are part of the formalization of licensing and taxation process. To improve the tax ratio and combat tax evasion, the government must integrate large shopping malls, merchants, wholesalers, and shopkeepers within the tax net. (Wani, 2018).

Similarly, money laundering prevention necessitates legislative action. Pakistan's government has taken a number of efforts to prevent the Hawala system from being abused. Because of the negative effects of IVTS, such as money laundering, revenue loss, corruption, and unregulated capital flight, all international IVTS are banned under the "Foreign Exchange Regulation Act Pakistan" 1947. Pakistan's major financial regulators are the "State Bank of Pakistan and the Securities and Exchange Commission of Pakistan" (SECP). They've set up anti-money laundering (AML) divisions to improve banking sector supervision. The same troops are concentrating their efforts on controlling the "Hawala system". SBP has implemented measures in Pakistan to limit the usage of "alternative remittance systems" ("ARS") and increase the use of regular remittance channels. To narrow the alternatives for exploiting ARS, the "State Bank of Pakistan" (2002) concentrated on building exchange firms to integrate informal moneychangers into the mainstream banking system. Businesses must register with the "Securities and Exchange Commission of Pakistan" and then apply to the "SBP" for an authorization to begin operations, as per this instruction. (Raza, 2017).

According to this article, informal banking channels must be regulated, regularized, and integrated into the formal economy. The probable use of the "Hawala system" for laundering money, funding terrorists, and other illicit gains is being monitored by local law enforcement such as the "National Accountability Bureau" ("NAB"), the "Anti-Narcotics Force" ("ANF"), the "Federal Investigative Agency" ("FIA"), and the "Directorate of Customs Intelligence and 
Investigations" ("CII"). In order to identify any unlawful behavior, these authorities should work together by exchanging information.

\section{Conclusion and Recommendations}

The formalization of the informal sector, according to this article, is important not only for raising tax revenues, but also for digital, skilled-based improvement of business activities, ramping up the operations and maintenance size of small businesses, increasing and diversifying production, and enhancing the lot of low-wage earners. To begin, the government should concentrate on integrating informal economic sectors, such as agriculture, into the official economy. Second, the "FBR" takes severe action against unlawful transportation systems and records them with a serial number at both the provincial and federal levels. This action will result in a legitimate income in the form of revenue tax, which will be collected through a suitable route. Regularization of tax rates is also required.

Lawmakers should also focus on the implications of informal financial channels like hawala and hundi, which continue to operate beneath the radar of the informal sector. In order to identify money laundering, the Pakistani government must focus on strengthening and encouraging the digitization of the economy. The digitization of the economy is critical to the formalization of Pakistan's economy.

\section{References}

Ali, M. (2019). "Informality and Taxation." The News. Retrieved 22 June 2021, from https://www.thenews.com.pk/print/516901-informality-and-taxation.

Bank, W. (2021). "Overview. World Bank." World Bank Publications. Retrieved 20 June 2021, from https://www.worldbank.org/en/country/pakistan/overview.

Burki, S. (2021). "Pakistan-The Economy of Pakistan". Encyclopedia Britannica. Retrieved 20 June 2021, from https://www.britannica.com/place/Pakistan/The-desert-areas.

Bokhari, J. (2020). "How to Formalize the Informal Economy". Dawn News, p. 1. Retrieved 20 June 2021, from https://www.dawn.com/news/1565728/how-to-formalise-the-informaleconomy.

Fogel, G., \& Agbi, E. (2021). "Shadow Economy and the Related Issues of Tax Evasion: Comparative Analysis among Canadian Workers." Retrieved 22 June 2021, from.

Fund, I. (2020). "What is the Informal Economy?" IMF.com. Retrieved 21 June 2021, from https://www.imf.org/external/pubs/ft/fandd/2020/12/what-is-the-informal-economybasics.htm.

Hub, H. (2021). "Informal Economy | The Homeless Hub". Homelesshub.ca. Retrieved 20 June 2021, fromhttps://www.homelesshub.ca/about-homelessness/education-training employment/informal-economy.

Kemal, M. (2007). "A Fresh Assessment of the Underground Economy and Tax Evasion in Pakistan: Causes, Consequences, and Linkages with the Formal Economy." Pakistan Institute of Development Economics. Retrieved 22 June 2021, from.

Khan, D. (2017). "Women in the Informal Economy in Pakistan Chalking out Ways to Bridge the Disconnect between the Feminist Movement, the Workers' Organizations and Political Parties." Friedrich-Ebert-Stiftung Pakistan. Retrieved 22 June 2021, from.

Kagan, J. (2021). "How Hawala Works." Investopedia. Retrieved 22 June 2021, from https://www.investopedia.com/terms/h/hawala.asp.

Mehboob, A. (2019). "Reasons for Tax Evasion in Pakistan." Arab News. Retrieved 22 June 2021, from https://www.arabnews.pk/node/1518521.

News, M. (2021). "Informal Sector - Definition and Meaning." Market Business News. Retrieved 21 June 2021, from https://marketbusinessnews.com/financial-glossary/informal-sectordefinition-meaning/.

Ponsaers, P. (2008). "Does the Informal Economy Link to Organised Crime?" International 
Journal of Social Economics. Retrieved 22 June 2021, from.

Qamar, A., Aslam, A., \& Chaudhary, M. (2021). "The Informal Economy of Pakistan: An Institutional and Fiscal Policy Perspective." Researchgate. Retrieved 22 June 2021, from.

Ranis, G. (2021). “Arthur Lewis' Contribution to Development Thinking and Policy.” Economic Growth Center Yale University. Retrieved 21 June 2021, From.

Raza, M. (2017). "The Hawala System in Pakistan: A Catalyst for Money Laundering \& Terrorist Financing." Forensic Research \& Criminology International Journal, 5(4). https://doi.org/10.15406/frcij.2017.05.00167

Scanner, S. (2021). "Negative Effects of Money Laundering on The Economy" | Sanction Scanner. Sanctionscanner.com. Retrieved 20 June 2021, from https://sanctionscanner.com/blog/negative-effects-of-money-laundering-on-the-economy132.

Vlcek, W. (2018). "Global Financial Governance and The Informal: Limits to The Regulation of Money." Crime Law Soc Change 69:249-264. Retrieved 22 June 2021, from.

WIEGO. (2021). "Rethinking Formalization"| WIEGO. Wiego.org. Retrieved 22 June 2021, from https://www.wiego.org/rethinking-formalization.

Wani, S. (2018). "Reforming Pakistan's Tax System: Evidence-Based Suggestions - IGC." IGC. Retrieved 22 June 2021, from https://www.theigc.org/blog/reforming-pakistans-taxsystem-evidence-based-suggestions/. 